\title{
Research on Study Abroad, Student and Staff Mobility, and Student Exchange in Comparative Education Scholarship
}

\author{
Bernhard T. Streitwieser \\ Northwestern University \\ Emily Le \\ University of California, Los Angeles \\ Val Rust \\ University of California, Los Angeles
}

\begin{abstract}
For many years there has been research on study abroad, student and staff mobility and international student exchange, however in the last two decades the volume and scope of this work has increased significantly. By now there are specific academic journals, a host of new books each year, expansive reports by international research organizations, and an increasing number of annual conferences that are all publishing on trends and issues related to this phenomenon. Yet surprisingly, in the comparative education scholarship much of this research still appears relatively infrequently in its main journals. This paper examines the seeming contradiction of, on the one hand, more student, staff and institutional participation in worldwide international education each year and new research accompanying this trend and, on the other hand, the relative scarcity of reflection on this activity in the core comparative education journals. In this article we take stock of international education themed research that has appeared in the past in a selection of comparative education journals, share the advice of the editors of these journals to future authors seeking to submit research on these areas, and conclude with our own reflections on the future nexus of scholarship in international education and comparative education.
\end{abstract}

\section{Introduction}

Today, the mobility of students and staff is a growing phenomenon in higher education activity around the world. Study in another cultural, geographic, and linguistic context offers a tremendous wealth of potential areas for research. However, while this activity in international education expands, surprisingly research on education abroad, student and staff mobility, and international student exchange still appears relatively infrequently in the leading comparative education journals.

This gap indicates an unfortunate missed opportunity to better bridge the two fields - usually described as more linked by their commonalities than separated by differences in focus or methods of inquiry. Often, the overriding description of comparative education is still that of an activity that is generally scholarly, interdisciplinary, and analytical. Meanwhile, international 
education is often seen as more practitioner oriented and concerned with academic mobility, international exchange, development aid and describing, examining and analyzing educational systems in foreign contexts, but less concerned with scholarly analysis that employs established or new theoretical and methodological lenses. While some aspects of this perception have merit, it is also somewhat misguided.

Rigorous research on the phenomenon of international education has the potential to greatly expand the scope of comparative education research, understanding of systems, theory development, and policy-making. Indeed, research on the wide scope of international education activity happening around the world today, and consideration of its myriad implications for all levels of education, types of programs and projects, and geographic regions offers a wealth of complementary paths and patterns of academic activity that raise interesting issues and intersect with many of the traditional and also newer themes also of interest to the scholarly comparative education community. Further, while much of the research on issues in international education is currently published in a wide range of academic journals - beyond international education publications but also in political science, intercultural study, sociology, psychology, and business management, among others - their themes and in many cases methodology and focus overlap strongly with areas that should also be of interest to the comparative education journals but still appear relatively infrequently in those publications.

The aim of this article is to briefly look at the publication activity in international education in a range of journals vis-à-vis their presence in the study abroad specific journals, and thereby hopefully encourage in the future more active inclusion of research and studies on international education - specifically on education abroad, student and staff mobility, and student exchangein the future dissemination of the comparative education scholarship.

To advance this development, this paper offers a discussion that is organized into three sections.

I) A brief overview of Comparative and International Education as historically linked fields and the advancement of international education research more actively within the overall comparative education scholarship.

II) A general accounting of the number of articles on 'study abroad,' 'student and staff mobility' and 'international student exchange' that have appeared over the past decades in five of the leading American, European and Australian and New Zealand comparative education journals.

III) A summary of the reflections by the editors of comparative education journals, who were contacted for this article and asked to give their general views on areas of research they regard as important in international education studies, and their advice for future contributors writing on these topics. This section also includes a brief discussion of international education themes that have been covered in these five comparative education journals since their founding. Our paper ends with our reflections on what the past themes covered and the expectations of journal editors for future work may imply for 
upcoming publication directions we can expect to expand the comparative education scholarship in tandem with increased and more rigorous studies in international education.

\section{Comparative and also International Education}

Since the inception of comparative/international education as an academic enterprise, the field has been "plagued by vagueness and a multiplicity of definitions and interpretations" (Kalovannaki and Kazamias 2009). Attempts have been made to clarify the meaning of various terms. In the initial volume of the first journal dedicated to the field, Friedrich Schneider attempted to establish a terminological base for the new discipline by going into great detail about the distinctions in the terms "international, foreign, and comparative pedagogy" (Schneider, 1931/32). In 1956, the first professional society to be organized for academics identifying with the field named itself the Comparative Education Society, although its name did not signal that foreign and international education would be excluded. However, after a decade, some prime movers of the field decided that it was appropriate to rename the society, because comparative education did not completely reflect their interests and foci. Thus, in 1968 the Board of Directors unanimously voted to change the name to the "Comparative and International Education Society" (CIES) (Swing, 2008), because these were seen as two distinct epistemic domains.

Three years prior to this action, the British Section of the Comparative Education Society in Europe (CESE) had been organized, and the British initially chose to exclude the word "International" from its name, mainly because international education was located elsewhere in the British academy. Britain had long had a focus on colonial studies and education in developing countries, but scholars involved in educational planning, as well as in education policy and practice in the developing world, rarely identified with comparative education because it encompassed the more academic, theoretical, and research frameworks for analysis of education in one or more countries, more often than not in the developed world. In contrast, at least in Britain, international education was oriented toward the developing world, and its focus was on practice and countries that had not yet fully developed their systems of education.

In 1979, the British Section of CESE declared itself to be the British Comparative Education Society. However, four years later they renamed the association the British Comparative and International Education Society, reflecting growth of the international development constituency in their group. In the next years, the international constituency grew stronger while the number of comparative educators diminished in numbers to the point that in 1997, the society renamed itself again the British Association for International and Comparative Education (Sutherland, Watson, and Crossley, 2007).

Though "comparative education" and "international education" represent distinct domains, Brickman and Fraser remind us that there is great overlap between the two. In other words, 
certain dimensions of international education can be and ought to be academic, theoretical, and research oriented, even though its focus remains on cooperation, understanding, and exchange. For example, NAFSA: The American National Association of International Educators as well as the Forum on Education Abroad recognize the importance of research and academic input in its enterprises and have each year over the past decade organized greater numbers of panels on research and theory at their annual conferences. ${ }^{1}$ Originally called the National Association of Foreign Student Affairs, NAFSA changed its name in 1990 to reflect its focus on all aspects of international education and exchange.

According to Theodore Vestal (1994), when the term "international" is used by comparative and international educationists, they usually refer to the following activities and concerns: (a) study of the education of other peoples in other countries; (b) educational exchanges and study abroad; (c) technical assistance to educational development in other countries; (d) international cooperation in educational development through international organizations; (e) comparative and cross-cultural studies in a variety of subjects and disciplines; and (f) intercultural education. Even though Vestal has given a long list of activities and concerns, his list is not exhaustive. For example, he neglects to mention the role that international schools play in the field (Bunnell, 2008). Some of Vestal's activities and concerns are clearly closely identified with comparative education, while educational exchanges, study abroad, technical assistance and development education are more akin to international education.

Professional groups such as the British Association for International and Comparative Education (BAICE) as well as the American Comparative and International Education Society (CIES) clearly include technical assistance and development education in their academic and professional agendas. At the annual CIES conferences, for example, representatives from organizations such as the Academy for Education Development, Chemonics International, the International Bureau of Education, Juarez and Juarez, the New Educational Fellowship, Open Society, Save the Children, UNESCO, UNICEF, and the World Bank make regular presentations alongside academic colleagues on panels. Academic programs in comparative education at research universities usually include courses related to international education in their curricula. At UCLA, for example, almost all comparative education students are expected to take courses on International Development Education. And the journal of the BAICE, Compare: A Journal of

\footnotetext{
${ }^{1}$ Val D. Rust organized such a panel at the 2009 annual conference of NAFSA in Los Angeles; Bernhard Streitwieser and Val Rust regularly present their research at these annual meetings. The 2011 Forum on Education Abroad conference in Boston, Massachusetts, saw it's strongest attendance yet with its theme addressing the link between education abroad and theories of international education, a good sign given that theory and study abroad has not been widely discussed in the study abroad literature to date. At the 2011 Comparative and International Education Society (CIES) conference in Montreal, Canada, 17 of the sessions directly addressed issues related to 'study abroad' and/or 'mobility,' many of those addressing specific initiatives currently being undertaken in Asia and the European Union.
} 
Comparative and International Education, publishes extensively on development education issues, and even publishes special issues on development. ${ }^{2}$ However, research that is focused directly on international education as it involves study abroad, mobility or international educational exchange--whether these activities are looked at as educational phenomena in their own right that warrant particular attention or as studies of student, faculty or staff participants and outcomes (Byram and Dervin, 2008) - have appeared less frequently.

\section{Research on 'Study Abroad,' 'Student and Staff Mobility,' and 'International Student Exchange' in the Comparative Education Journals}

In this section we report on our efforts to tabulate the research published on 'study abroad,' 'student and staff mobility,' and 'international student exchange' in five of the main comparative education journals over the past decades: Comparative Education Review (1957-2010), Compare: A Journal of comparative and International Education (1969-2010), The International Education Journal (IEJ): Comparative Perspectives (1999-2011), Comparative Education (1964-2010), and Research in International and Comparative Education (1996-2011).

While hardly an exhaustive list of journals representing the many disciplinarily diverse publications where comparative education scholarship can appear, these five journals were selected as obvious places where much of the comparative education scholarship has indeed been published in the English language to date. Although we could have searched many more journals that publish research on international education, we purposefully limited ourselves using fairly basic criteria: education journals with 'comparative' or 'compare' in their titles, journals that represent several comparative education societies around the world, and journals where indeed much of the international education research that is deemed to be of a comparative nature has been published. Finally, we could also have searched numerous recent book publications and research reports, ${ }^{3}$ but doing so would also have gone far beyond the scope of this paper. It was not our intention to provide a metric to measure what constitutes a deficient, sufficient or overcoverage of the research themes in these publications - a task that goes beyond the scope of our study and may not even be possible. However, we made an effort to search for articles in a deliberate way that helped us to distinguish what we felt were the differences between articles covering some aspect of our themes of interest in a 'substantive' way and articles our keyword searches merely identified but which were not sufficiently related to our search goals. We

\footnotetext{
${ }^{2}$ For example, see volume 31, \#3 of Compare.

${ }^{3}$ For a small selection of examples see: Altbach, Reisberg, and Rumbley's Trends in Global Higher Education: Tracking an Academic Revolution. (Boston College Center for International Higher Education, 2009); Childress' The twenty-first century university: Developing faculty engagement in internationalization (Peter Lang, 2009); deWit's Trends, Issues and Challenges in Internationalisation of Higher Education (CAREM, 2011); Forest and Altbach's International handbook of Higher Education (Springer, 2011); Jones and Brown's Internationalising Higher Education (Routledge 2007); Kelo, Teichler and Waechter's Student Mobility in European Higher Education (Lemmens, 2006); Knight's Higher Education in Turmoil: The Changing World of Internationalization (Sense, 2008); Lewin's Handbook of Practice and Research in Study Abroad: Higher Education and the Quest for Global Citizenship (Routledge, 2009); and Stearns' Educating Global Citizens in Colleges and Universities: Challenges and Opportunities (Routledge, 2009).
} 
operationalized our understanding of 'substantive' to imply a discussion in which one or several of the above mentioned themes are the direct focus of the article, not merely mentioned in the body of a paper dealing with a different thematic area.

Using the terms 'study abroad,' 'student and staff mobility,' and 'international student exchange' free of quotation marks in our search, we were able initially to capture the largest number of possibly relevant articles within each journal. Searches were conducted through the online websites hosting the respective journals: JSTOR for the Comparative Education Review; Taylor \& Francis for Compare and Comparative Education; Symposium Journals for Research in Comparative and International Education; and the IEJ.CJB.NET website hosted by Flinders University. We then employed further search terms, including 'education abroad,' 'foreign study,' and 'international education,' to check if the same articles also appeared under these terms. Since 'study abroad' is commonly referred to as 'student mobility' in Europe, we looked for the total number of study abroad-related articles using the query 'study abroad' and also ran a separate query using 'student mobility' as a way to capture all potential articles related to study abroad generally. The majority of the articles we found in Compare and Comparative Education Review came up under the 'study abroad' query, while those in Comparative Education were primarily classified using 'student mobility' and those in the International Education Journal: Comparative Perspectives used 'student exchange.' When we expanded our search terms to also include 'international student exchange' the numbers grew slightly but not dramatically.

While our list of possible terms and synonyms could have been even larger and more expansive - to also include, for example, 'foreign education,' 'foreign study,' 'internationalization,' and other closely related terms - our search nevertheless initially yielded a large body of articles in each journal, which we then had to narrow down further for our second analysis. In this way, for example, our initial search of the Comparative Education Review led to 604 articles but the narrowing down process then resulted in only 19 we deemed to be 'substantive' enough for further analysis in terms of our focus. Results that came up in the initial search included all articles that had the search term within the title or body. The search term was entered without parenthesis around it so it would include as many results as possible. This led to many non-relevant articles appearing under the initial search. Many of these articles were not focused on study abroad but may have mentioned it once or twice in passing. Other articles appeared because they contained the words 'study' and 'abroad' but not necessarily together to mean 'study abroad.' Once we narrowed down our initial search, we were able to conduct a more detailed review of the remaining articles to determine their relevance to our themes of interest and study the specific topics and questions, research methods and findings that were addressed. Our analysis of that smaller stack began by looking first at article title and abstracts and then went into a more detailed review of the contents of the article itself. The summary of our search is illustrated in the table below. 


\begin{tabular}{|l|l|l|l|l|}
\hline Journal & Study Abroad & Student Mobility & $\begin{array}{l}\text { International } \\
\text { Student Exchange }\end{array}$ & $\begin{array}{l}\text { Total substantive } \\
\text { articles on all } \\
\text { themes of interest* }\end{array}$ \\
\hline $\begin{array}{l}\text { Comparative Education } \\
\text { Review }^{45}\end{array}$ & $\begin{array}{l}604 \text { search results } \\
\text { Total relevant: } 1\end{array}$ & $\begin{array}{l}545 \text { search results } \\
\text { Total relevant: } 2\end{array}$ & $\begin{array}{l}413 \text { search results } \\
\text { Total relevant: } 2\end{array}$ & 19 \\
\hline $\begin{array}{l}\text { Compare: A Journal of } \\
\text { Comparative and } \\
\text { International } \\
\text { Education }\end{array}$ & $\begin{array}{l}168 \text { search results } \\
\text { Total relevant: } 12\end{array}$ & $\begin{array}{l}186 \text { search results } \\
\text { Total relevant: } 7\end{array}$ & $\begin{array}{l}225 \text { search results } \\
\text { Total relevant: } 8\end{array}$ & 12 \\
\hline $\begin{array}{l}\text { The International } \\
\text { Education Journal: } \\
\text { Comparative } \\
\text { Perspectives (IEJ) }\end{array}$ & $\begin{array}{l}\text { 6) } \\
\text { Total relevant: } 6\end{array}$ & $\begin{array}{l}111 \text { search results } \\
\text { Total relevant: } 22\end{array}$ & $\begin{array}{l}130 \text { search results } \\
\text { Total relevant: } 23\end{array}$ & 23 \\
\hline $\begin{array}{l}\text { Comparative Education } \\
\text { Journal }\end{array}$ & $\begin{array}{l}256 \text { search results } \\
\text { Total relevant: } 1\end{array}$ & $\begin{array}{l}338 \text { search results } \\
\text { Total relevant: } 2\end{array}$ & $\begin{array}{l}311 \text { search results } \\
\text { Total relevant: } 2\end{array}$ & 3 \\
\hline $\begin{array}{l}\text { Research in } \\
\text { Comparative and } \\
\text { International } \\
\text { Education }\end{array}$ & $\begin{array}{l}38 \text { search results } \\
\text { Total relevant: } 2\end{array}$ & $\begin{array}{l}34 \text { search results } \\
\text { Total relevant: } 1\end{array}$ & $\begin{array}{l}33 \text { search results } \\
\text { Total relevant: } 1\end{array}$ & 4 \\
\hline
\end{tabular}

Table I. Search of Comparative Education journals using terms 'study abroad, student mobility, international student exchange, education abroad, foreign study', and 'international education'

In terms of the Comparative Education Review (CER), a special issue in 1984 included seven of the 19 articles of relevance. Of the remaining, five were published before 1974 and only four after 1990. In the journals Compare and Comparative Education Review all the articles appeared under the search 'study abroad' while only select articles also appeared when the other search terms we used. In the journal Compare using 'study abroad' as our search term, 168 search results initially appeared but only 12 articles were significantly focused on study abroad. A search was also conducted using the terms 'student mobility' and 'international student exchange' with 7 and 8 articles respectively in which student mobility or international student exchange was the main focus of the article. All of the articles that appeared using our 'student mobility' and 'international student exchange' searches also appeared when we used 'study abroad' as our search term in Compare, indicating that 'study abroad' is their dominant term of use. The term 'study abroad' was also the dominant term in the Comparative Education Review, while 'international student exchange' was the dominant term used in the International Education Journal: Comparative Perspectives. In our search of Comparative Education and Research in International and Comparative Education, use of the additional search terms 'foreign study,' 'education abroad,' and 'international education,' did not lead to a larger number of relevant articles.

\footnotetext{
${ }^{4}$ CER is the official journal of the Comparative and International Education Society (CIES) in the United States.

${ }^{5}$ The numbering here indicates the last issue included in our search. Since the journals have multiple issues per volume, the last issue wasn't published yet when we conducted our review. Due to the nature of our search and our reliance on searching electronically, we were only able to review those issues available online through electronic databases.

${ }^{6}$ The IEJ is authorized and sponsored by the Australian and New Zealand Comparative and International Education Society (ANZCIES)
} 
While our searches did not include more extensively studying additional journals or the many books and reports published on themes of study abroad, mobility, and exchange, we were curious about future scholarship we can expect on these areas. One way to look at that was to mine some of the research at the Center for Global Education, formerly located at Loyola Marymount University in Los Angeles and now at the University of California, Los Angeles, and its clearing house for thousands of research studies on American students who go abroad and international students who come to the United States. In light of that question we reviewed some of the recent doctoral dissertations that have been published on study abroad and are available on the ProQuest Dissertations and Theses A \& I database. Using this search engine, we found many more studies on international education since 1965, approximately 257 of which exclusively focus on study abroad. We conducted that search using the term 'study abroad' and by manuscript type of doctoral dissertation, and only those published in English. Thus, although somewhat limiting our research, we found it interesting that 210 of these studies were written only within the last 11 years. Of the dissertations we studied, the following were the five topics were most researched on study abroad: Intercultural competence and development; personal growth and identity development; language learning and acquisition; administration and policy; recruitment, participation and re-entry.

While most of these dissertations came out of education departments, they represented a wide range of disciplines, including psychology, health and kinesiology, engineering, linguistics, and Spanish. Under the search term 'international student exchange' only six dissertations appeared under that keyword search while 'student mobility' only had two that specifically focused on study abroad. The majority of the dissertations and thesis under 'student mobility' refer to educational access and equality, not international education exchange. An additional research using the term 'international students' by index term (keyword) resulted in 400 dissertations, with 348 alone produced since 2000. Using keyword classification, we found that the dominant search term was 'study abroad' and 'international student exchange.' Notable is that 14 dissertations in the last few years originated from one institution, the University of Minnesota, which has a strong comparative and international development education graduate program and a relatively new doctorate of education program for international educators, with a particular focus on study abroad and international exchange administration and development. Prior to 2003, only two dissertations focused on study abroad.

While we can see from the above discussion that our international education themes of intereststudy abroad, student and staff mobility, and international student exchange-were not largely covered in any of the five major comparative education journals we searched, these themes are, however, being addressed with increasing vigor by emerging scholars that are coming out of graduate programs. This rather striking increase in dissertations on international education and study abroad appears to indicate that this has become an especially interesting research area for young scholars over the last decade. This should bode well for the future research output in these areas. It may also signal that new directions in international education research will likely be 
explored in the future. For now, though, we feel that the greater productivity on international education by young scholars, on the one hand, but the still relative lack of publication of that work in the comparative education journals, on the other hand, indicates several possibilities: 1) Many dissertations remain unpublished or may not yet be seen as meeting the standards for publication in the top comparative education journals; 2) The topics covered may not have so far been deemed appropriate by the editors of these publications, if they were even submitted for review; 3) The comparative education journals may be slow to take interest in this line of research or may not regard it as rigorous enough or relevant scholarship. The question remains, then, as to whether this trend will change over time or not if the quality of submissions on international education topics is not the primary impediment to its wider publication. We put some of these questions to comparative education journal editors themselves and discuss their answers in the next section.

Overall, our search in the five comparative education journals is not meant to suggest that they are necessarily insufficiently addressing research on study abroad, student and staff mobility, and international student exchange. However, as the next section elaborates, published scholars working in international education have encouraged more cross fertilization between research on international education and comparative education scholarship, and voiced their hope that this work become more frequently disseminated in the existing comparative education journals in the future. Further, the editors of each of these journals also welcome more study of these areas and are eager to offer concrete suggestions about future topics of interest to them and the level of scholarship they expect in submissions. Finally and as noted already, beyond these five publications there are other academic journals - albeit not focused on comparative education per se- that publish work on themes of international education and cover these areas more extensively. These include the Journal of Studies in International Education; Frontiers: The Interdisciplinary Journal of Study Abroad; the International Journal of Intercultural Relations; the Journal of Research in International Education; the International Journal of Educational Research; and, Higher Education, among others. Unfortunately, the scope of this paper did not permit us to also conduct a study of their coverage on our specific themes of interest as well.

The second step of the analysis is detailed in Section III below, where we discuss the major themes that each of the five comparative education journals cover. We then offer comments by the editors of these journals, who were contacted in preparation for this article. Their comments are anonymously summarized and we greatly appreciate their insights and reflections on the state of the art and the guidelines they have generously provided to scholars who wish to submit manuscripts in the future.

\section{Recent Research Themes Published in International Education}

Comparative education journal editors acknowledge the need for more work on themes in higher education to appear in the comparative education scholarship. A February 2011 editorial in the Comparative Education Review advocated first among a long list of "understudied areas" that 
there be more "submissions analyzing the politics of international education and cultural exchange" in the form of more policy studies particularly on U.S. based international education activity in the future. ${ }^{7}$ This "open invitation" requested in particular papers on the "diplomatic and cultural impact" of programs such as Fulbright (p. 3). In a 2007 editorial in the International Education Journal: Comparative Perspectives, the editor also expressed his hope to "engage a larger audience of contributors and readers who consider themselves not only as researchers in the field of comparative and international education, but who work in more specific subject areas such as intercultural studies, international development, internationalisation and globalization," among other areas noted (p. 1443).

Before we summarize the comments from the journal editors we contacted, we provide in Table II below a brief overview of the areas within study abroad, student and staff mobility, and international student exchange that have been covered in the five noted comparative educational journals during the decades since their founding.

\begin{tabular}{|c|c|}
\hline The 5 Journals & $\begin{array}{l}\text { Topics covered related to our three areas of interest: Study Abroad; Student \& } \\
\text { Staff Mobility; International Student Exchange }\end{array}$ \\
\hline \multirow[t]{5}{*}{$\begin{array}{l}\text { Comparative Education } \\
\text { Review }\end{array}$} & $\begin{array}{l}\text { 1960s } \\
\text { A bibliography of study abroad research; reintegration of Indian students into the } \\
\text { employment market; a study of Israeli history textbooks and Israeli's abroad; a survey } \\
\text { of American study centers in Germany and their integration efforts and impact on } \\
\text { policy. }\end{array}$ \\
\hline & $\begin{array}{l}\text { 1970s } \\
\text { A case study of Peruvian students trained in the United States. }\end{array}$ \\
\hline & $\begin{array}{l}\text { 1980s } \\
\text { May } 1984 \text { special issue: A bibliography of research on international students and study } \\
\text { abroad programs; international students and changes in the fee structure in Britain; the } \\
\text { impact on national development of African graduate students trained abroad; } \\
\text { challenges to the American higher education system for accommodating foreign } \\
\text { graduate students; the economic and policy impact of study abroad on developing } \\
\text { countries. }\end{array}$ \\
\hline & $\begin{array}{l}\text { 1990s } \\
\text { Japanese and Chinese students and perceptions of gender roles as students in the } \\
\text { United States; Chinese students and the influence of studying in the United States; } \\
\text { Indonesian students and predictors of success for graduate study in the United States. }\end{array}$ \\
\hline & $\begin{array}{l}\text { 2000s } \\
\text { International students in the United States and conceptions of citizenship identity; } \\
\text { American study abroad students in Australia and reflections on national identity. }\end{array}$ \\
\hline
\end{tabular}

\footnotetext{
${ }^{7}$ Surprisingly, as of when we contacted the journal, the CER had only received one submission related to that particular topic in response to their editorial column.
} 


\begin{tabular}{|c|c|}
\hline & $2010+$ \\
\hline \multirow{5}{*}{$\begin{array}{l}\text { Compare: A Journal of } \\
\text { Comparative and } \\
\text { International Education }\end{array}$} & 1970s \\
\hline & $1980 s$ \\
\hline & $\begin{array}{l}\text { 1990s } \\
\text { Pilot study results of one Dutch university's internationalization efforts. }\end{array}$ \\
\hline & $\begin{array}{l}\text { 2000s } \\
\text { The impact of a social science course on the learning experiences of European } \\
\text { Erasmus students at a university in Finland; a case study of Chinese graduate students' } \\
\text { intercultural learning experiences at one British university; report of findings of a } \\
\text { study of Chinese student integration at UK universities using an existing theory of } \\
\text { internationalization; a historical study of the reintegration of Japanese learners after a } \\
\text { prolonged period of living and studying overseas; a study of Chinese female } \\
\text { immigrants to the UK and their cultural adjustment process in relation to the author's } \\
\text { own experiences. }\end{array}$ \\
\hline & $\begin{array}{l}\text { 2010+ } \\
\text { Developing a theory on the perspectives of Mainland Chinese students studying at } \\
\text { Singaporean universities; findings of a study of first year international students at four } \\
\text { UK universities; a study of the experiences of two groups of women from Middle } \\
\text { Eastern countries studying in neighboring countries; case studies of the learning } \\
\text { outcomes of international graduate students in Australian higher education; a study of } \\
\text { Central and Eastern European university students at one UK university and their } \\
\text { attitudes and motivations toward learning; a small qualitative study of the reintegration } \\
\text { experiences of Chinese students after graduate study overseas. }\end{array}$ \\
\hline \multirow{2}{*}{$\begin{array}{l}\text { The International } \\
\text { Education Journal: } \\
\text { Comparative } \\
\text { Perspectives }\end{array}$} & 1990s \\
\hline & $\begin{array}{l}\text { 2000s } \\
\text { A survey study of two groups of North American students and their motivations to } \\
\text { engage in study abroad, uses an established theory, offers policy recommendations; } \\
\text { influencing factors in the recruitment of Chinese students to study at Australian } \\
\text { universities, with policy recommendations; a case study of a sample of Thai graduate } \\
\text { students and their experiences in a distance learning course at one Australian } \\
\text { university, with policy recommendations; using an established instrument to study } \\
\text { British youth in China and in the UK and their international awareness, respect for } \\
\text { other cultures and feelings of national identity; a questionnaire study of a small sample } \\
\text { of Indonesian postgraduate students and their adjustment experiences at Australian } \\
\text { universities, with policy recommendations; a case study of Japanese students in an } \\
\text { Australian high school and perceptions of cultural identity, with policy } \\
\text { recommendations; a case study of the counseling services and expectations of Chinese, } \\
\text { Australian and North American university students, using an established instrument, } \\
\text { with policy recommendations; a qualitative study of the psychological adjustment } \\
\text { experiences of Korean students at one university in Japan; a discussion of the } \\
\text { challenges of teaching critical thinking skills to international students, primarily from } \\
\text { Asia, at Australian universities, a suggested new approach and policy considerations; a } \\
\text { study of the internationalization of one university and its impact on visiting } \\
\text { international students and pedagogy, with policy recommendations; a study of Thai } \\
\text { student decision making to study overseas; a small interview study of a group of } \\
\text { Taiwanese students in the U.S. and integration and identity issues; a comparative }\end{array}$ \\
\hline
\end{tabular}




\begin{tabular}{|c|c|}
\hline & $\begin{array}{l}\text { analysis of different approaches among regional Australia cities to attracting the } \\
\text { international student market; report of results of a project to support English language } \\
\text { learners through a course at one Australian university, with policy recommendations; a } \\
\text { discussion and analysis of policies and activities related to addressing the counseling } \\
\text { needs of international students in New Zealand; a case study of the academic and } \\
\text { cultural adjustment challenges of a small group of Asian students studying at one U.S. } \\
\text { university, use of an established model, with policy recommendations; a study of the } \\
\text { social and cultural adjustment difficulties of international students generally and with } \\
\text { a focus on Iranian students in Scotland in particular, with policy recommendations; an } \\
\text { interview study of the language difficulties of students from five Asian countries } \\
\text { studying in Australia, with suggestions for remediation; a report on faculty perceptions } \\
\text { of international graduate students' feelings of isolation from host nationals; report of } \\
\text { one Australian university's policy to test international student language proficiency } \\
\text { using an established measurement device and grade point average, with } \\
\text { recommendations for stemming attrition; construction and testing of a scale to } \\
\text { measure family influence on Thai students' decisions to study abroad; a small survey } \\
\text { study of a sample of Asian students at one Australian university and perceptions of } \\
\text { quality in education, with policy recommendations; a study of a small sample of } \\
\text { Australian teachers' language awareness through a short-term experience in South } \\
\text { Korea. }\end{array}$ \\
\hline & $2010+$ \\
\hline \multirow[t]{6}{*}{ Comparative Education } & 1960s \\
\hline & $\begin{array}{l}\text { 1970s } \\
\text { Student mobility in Latin American and challenges related to recognition of course } \\
\text { work completed elsewhere. }\end{array}$ \\
\hline & 1980s \\
\hline & $\begin{array}{l}\text { 1990s } \\
\text { An assessment of the European Erasmus program in light of the relationship between } \\
\text { the program's present day goals and the humanitarian ideals of its historical namesake, } \\
\text { Erasmus of Rotterdam. }\end{array}$ \\
\hline & $\begin{array}{l}\text { 2000s } \\
\text { A systems level analysis of official documents related to student mobility in the } \\
\text { European Union and efforts to harmonize higher education systems. }\end{array}$ \\
\hline & $2010+$ \\
\hline \multirow[t]{2}{*}{$\begin{array}{l}\text { Research in Comparative } \\
\text { and International } \\
\text { Education }\end{array}$} & $\begin{array}{l}\text { 2000s } \\
\text { The experiences of U.S. study abroad students and individual and institutional factors } \\
\text { that facilitate their experiences; a discussion of student affairs professionals and their } \\
\text { role in facilitating international students' educational experiences; Singaporean } \\
\text { students' decisions to study in Australian universities and development of a model of } \\
\text { decision-making; a historical study using archival records of the development of } \\
\text { Anglo-German university educational exchange programs after the Second World } \\
\text { War. }\end{array}$ \\
\hline & $2010+$ \\
\hline
\end{tabular}


Table II. Thematic areas covered in the five comparative education journals reviewed

If the search criteria, the specific keywords used, and our methods of finding and analyzing articles is accepted as valid we can draw a number of interesting conclusions from Table II. Among other things, these findings shed light on a) the magnitude of research output over time, b) the focus on particular research questions, c) the concentration on particular countries or areas of the world, d) the concentration on types of students and where they come from, and e) types of studies, sample sizes, and research methods used.

\section{a) Magnitude of Research Output over Time}

First and most obvious, some of the five journals we considered have disseminated more international education research along our three main themes of interest than have some of the others. Further, publications on issues in international education have been irregular when considered in terms of the different decades in which they appeared.

For example, the International Education Journal: Comparative Perspectives has published a great deal of international education work in the 2000s, the first full decade since it was established, while the Comparative Education Review and Comparative Education, two more established and older comparative education journals, have published relatively little over the same period. While there was a sudden output of relevant articles in the Comparative Education Review in the mid 1980s, this was confined to the special May 1984 issue on "Foreign Students in Comparative Perspective." The two decades prior and the two latter have seen relatively little output: five relevant articles in the 1960s and 1970s combined, and five relevant articles in the 1990s and 2000s combined. The online journal, Research in Comparative and International Education has published relatively fewer articles on international education in the 2000s (only four) and yet this has been three times more than the older and more established journal, Comparative Education, which published only one article of relevance to our themes in the previous decade. The journal, Compare, did not publish articles of relevance to our search in the 1970 s and 1980s and only one in the 1990s, but then in the decade of 2000 greatly expanded its output to five publications in the 2000s and another six in only the first two years of 2010-11. Clearly, the research output has increased dramatically in the decades of the 1990s and 2000 and particularly in the more newly established comparative education journals.

\section{b) Focus on Particular Research Questions}

A large number of the papers we identified as relevant focused either on the student level (i.e., Chinese students in Australia) or on the level of individual institutions (i.e., a program to integrate Chinese graduate students at one UK university). At the student level, for example, many articles addressed issues students face related to intercultural adjustment (psycho-social, linguistic, academic) either into the host culture or back into their home culture, their motivations to study elsewhere and related family and other influences on personal decision making, and the support and services foreign students need to succeed. Some of these papers were focused on as 
few as five students, or on only one academic course, while others had samples closer to 50 or 100. Fewer articles looked at international education from a wider angle, whether from a systems-level perspective (i.e., mobility in the European Union) or at the national policy level (i.e., American higher education and accommodating foreign students). While there were certainly pieces that took a wider, more macro-level perspective and thus in some cases included much larger samples, they have appeared less frequently in these journals to date. A number of papers also shared results of particular policies or programs, much like an internal institutional report might, but then often offered only relatively short discussions in the conclusion that addressed wider potential implications or made policy recommendations.

\section{c) Concentration on Particular Countries or Areas}

While papers in the Comparative Education Review represented the widest range of world regions and students coming from different academic systems (i.e., Asia, Europe, Latin America, Africa, the United States, and Australia and New Zealand), the other four journals - of course with notable exceptions - generally published papers on issues and populations geographically closer to where the journal is physically based. This was most evident with the International Education Journal, where the overwhelming majority of articles were on students, institutions and issues related to the Asian and Australasian education systems.

\section{d) Concentration on Students from Particular Areas of the World}

Much of the study of international students in all of these journals was focused on or related to issues that concern students from Asia. This is not necessarily surprising given the large number of Asian students who in the past decade have sought higher education in other regions of the world, most notably the United States, the United Kingdom, and Australasia. This focus on Asian students has been strongest in the decade of the 1990s and 2000. Notable is that in the official BAICE journal, Compare--the official journal of the British Association for International and Comparative Education--a particularly large number of articles of relevance to our search dealt with Asian students. While some discussion of students from Latin America and Africa was published in some of these journals in the 1960s and 1970s, there has been seemingly very little attention to this demographic again in the 1990s and 2000s, where more attention has turned, as noted already, to Asia and not surprisingly after 9/11 to the Middle East. Attention to European issues and students has not seen any significant growth, although the impact of the end of the Cold War and the Bologna initiative might account for slightly more articles in the 1990s and 2000s. Nearly all of the papers related to our area of interest looked at students at the level of higher education, with only very few looking either at the secondary school level or at adult learners or immigrants. This is not surprising given that study abroad, student and staff mobility and international student exchange is generally an activity that involves participants in higher education.

e) Types of Studies, Sample Sizes, and Research Methods Employed 
The types of studies reported most frequently in each of the journals were case studies with relatively small numbers of students and relatively often focused on only one institution. These studies generally relied on samples of students who either filled out open-ended surveys, were interviewed individually or in focus groups, or some combination of both. Fewer research studies were based on statistically large samples or national databases. Some papers also reported using an established scale or theoretical model to test a specific context, or in other cases used their internal data to generate new models or categories or to suggest a new scale or other measurement instrument.

Finally, it would seem obvious that changes in the makeup of editorial teams as well as significant world political, economic and social developments have a great deal to do with a journal's increase or decreased attention to particular geographic regions or research questions. While our analysis did not account for this and thus we are unable to make a definitive statement on the finding, it does not seem especially surprising. An example of the latter is the increase of articles looking at students' perceptions of identity — a tendency that has been associated with greater mobility and some of the trends related to ubiquitous and growing discussions of globalization.

\section{Suggestions from Journal Editors for Future Submissions}

In addition to identifying the research areas covered in each of the five comparative education journals we reviewed and have just illustrated in Table II, we also asked the editors of each of these journals to share with us what they regard as research directions in international education - again with a particular focus on study abroad, mobility and exchange - they welcome in future submissions. ${ }^{8}$ The list below summarizes a general consensus among the editors, however there was not unanimity on every observation or suggestion.

To begin with, the editors as a group emphasized that a submission should always and at a minimum meet the general standards expected for inclusion in a peer reviewed journal. These are

\footnotetext{
${ }^{8}$ Our email was worded as follows: "I am currently working on an article for a special issue I am guest editing for the online journal, Research in International and Comparative Education. The issue is devoted to discussing research on education abroad, student and staff mobility, and international student exchange and its place in the broader comparative education scholarship. I hope to include in the article some general information about what the editors and reviewers of submissions to your journal generally look for when they receive work related to research on international education (specifically study abroad, mobility and student exchange). Besides information for contributors available on the journal's website, would you be able to share a few pointers about what you look for in particular when considering research in these areas and what makes a submission stand out as worthy for publication? Also, are there any particular editorials I should look at in your journal where you, or your editorial team, have encouraged more submissions on international education topics or talked about what thematic areas might be of special interest? Finally, are there any articles on these themes that you feel could be particularly good models I could point to for future contributors? I am contacting other journal editors right now as well and will summarize everyone's general advice and offer it as helpful guideposts for future contributors. Any advice from you would be greatly appreciated. Thank you.
} 
that submissions should be relevant to the focus of the journal, rigorous in their approach and analysis, grounded in the appropriate literature and context, and seek to make an original and significant contribution to the existing literature. Beyond that, they offered the following additional reflections:

- The editors seek to publish more work on themes of international education and are eager to receive more high quality submissions. There have been too few submissions on international education, study abroad, mobility, and exchange in the past. However, journal rankings have added pressure on journal editors to publish only papers of the highest quality, so standards for acceptance in the best journals are extremely high.

- The research must include comparative elements that lend themselves to critical analysis and reflection.

- The research should have a strong and well-articulated theoretical perspective that is supported by a synthesized and relevant base of literature. Good articles stand out by analytically synthesizing related literature so that a theoretical perspective emerges.

- Research that is overly descriptive often fails to connect a specific case to the broader literature, whereas it should contribute to the general understanding of issues relating to international education, study abroad, mobility, etc. Mere summaries of program evaluations, lessons learned from projects or reports of findings based on case studies or one-institution studies are generally of little interest.

- The research needs to be put into a proper context that relates the particular argument to the general background of the country/region or institution in question as well as to a relevant literature.

- The editors would like to see more work on international education that also comes with a broader policy and systems level analysis and discussion of implications.

- When possible, the editors would like to and do make an effort to offer guidance for articles that have been rejected, both in order to justify their actions and also not discourage future submissions.

- One helpful exercise for those interested in the Comparative Education Review's editorial process is to download and read through the open file of editorial correspondence. This offers a clearer sense for the types of criteria that may be used for evaluating a range of types of articles. Unfortunately, this correspondence, however, only offers insight into articles that have been accepted.

- Another helpful insight is to look at the video interview with the editors of the journal Compare as a way to get insight into their editorial decision making process. This video is available on the journal website.

- Some of the journals would like to encourage more special issues as a way of keeping the research robust and current. Calls for special issues are generally advertised through 
WCCES, CIES, and ANZCIES, among other outlets and are a good opportunity for theme-specific submissions.

One reason why we chose to take a closer look at the presence, type and frequency of international education research within the comparative education literature is that criticism of this work - as pointed out by the journal editors cited above - is not new and has in fact been repeatedly invoked in the past. In the leading U.S. and European comparative education journals over the past 50 years, study abroad as a phenomenon of international education has been relatively under analyzed in academically rich, theory-driven and empirically rigorous ways. Leading voices in the field of international education have previously criticized the research on international education as sometimes too thematically narrow, overly oriented toward practitioners, and unevenly accessible within the established higher education journals. Assessment of this situation over time has become somewhat more positive, however. In his 2011 review of the state of international education, Hans deWit voiced more optimism that dissemination as well as the sources of research on international education had "developed rapidly" (p. 95) and that one could now witness "an ever increasing diversity" of thematic coverage and range of scholarly contributions (p. 102).

\section{Conclusion}

\section{A Missed Opportunity?}

The argument put forth in this paper has highlighted that while traditionally comparativists have drawn a general distinction between comparative education on the one hand and international education on the other, in reality this may in fact signal a missed opportunity to more firmly integrate the two fields. The active research that today is taking place on issues related to international education, including research on study abroad, student and staff mobility and educational exchange, offers a wide diversity of ways to broaden the comparative education scholarship. Neglecting significant areas of international education research in the comparative education literature not only represents a lost opportunity for comparativists but is also surprising given the long history of activity in international education and the fact that today so many students and professionals alike engage in international learning today. Just to take study abroad as an example of one of the major activities under the wider umbrella of international education, the exponential growth in student participation rates over the past decade, driven perhaps largely by the ubiquitous public rhetoric around globalization, poses major pressures and competing challenges that are fertile ground for research. For many students, an experience of studying elsewhere represents not only a formative and often transformative experience, but may ultimately be the most significant comparative experience they will have in their lives. While the implications of this are not lost on institutions of higher learning — where the drive expand study abroad opportunities, internationalize their campuses, and expand their global outreach has grown exponentially over the last decade-for scholars of comparative education there is much 
to learn through examining international study in all its complexity and to draw into the wider comparative education theory, methodology and literature.

Although the default mode in some study abroad and international offices may still be an over reliance on quick, superficial program evaluations, calls to engage in deeper research to more fully understand the totality of the study abroad experience have grown more vocal in recent years. Research informed by an expanding body of work and supported by sound methodology and valid theoretical frameworks is increasingly available for consumption. More panels and workshops reflecting critical analysis of issues in international education are organized each year at the international meetings of the Forum on Education Abroad, NAFSA: Association of International Educators, the Council on International Educational Exchange, the American Educational Research Association, the European Educational Research Conference, and the conferences sponsored by the European Comparative Education Society, the U.S. Comparative and International Education Society, the Comparative Education Society of Asia, the Australia and New Zealand Comparative and International Education Society, and the World Council for Comparative Education Societies, to name only the largest gatherings. Some of this discussion then appears in a growing number of increasingly respected peer-reviewed journals, many focused specifically on international education. Arguably, this growth in research and dissemination is altering what is sometimes still popular perception of study abroad as an activity students engage in and administrators facilitate but not one that can is also richly academic and worthy of scholarly attention and deep, critical reflection.

Through a review over the past decades of the inclusion of international education scholarship in at least some of the leading comparative education journals, we have sought through this article to advocate that research on the phenomenon of international education should have a greater presence in the development of the comparative scholarship in the future. 


\section{References}

Barber, E., Altbach, P. G., and Myers, R. (1984). Introduction: Perspectives on Foreign Students. Editorial in Comparative Education Review, 28(2), 163-167.

Brickman, W. and Fraser, S. E. S. (1968). A History of International and Comparative Education. Boston: Scott, Foresman and Co.

Byram, M. and Dervin, F. (Eds.) Students, Staff and Academic Mobility in Higher Education. Newcastle, UK: Cambridge Scholars Publishing.

Denman, Brian D. (2007). Editorial. International Education Journal: Comparative Perspectives, Vol 8, No 3 (December 2007). Adelaide: Shannon Research Press (ISSN: 1443-1475).

deWit, H. and Urias, D. (2011). An Overview and Analysis of International Education Research and Resources. In H. deWit (Ed.) Trends, Issues and Challenges in Internationalisation of Higher Education (pp. 95-103). Amsterdam: Hogeschool van Amsterdam.

Editorial. Comparative Education Review, 55(1). 1-7.

Swing, E. S. (2008). The Comparative and International Education Society (CIES). In V. Masemann, M. Bray and M. Manzon (Eds). Common Interests, Uncommon Goals: Histories of the World Council of Comparative Education Societies and its Members. CERC Studies in Comparative Education, 21. Springer.

Vestal, T. (1994). International Education: Its History and Promise for Today. Westport, CT: Greenwood. 


\section{Authors}

Bernhard T. Streitwieser, Senior Research Associate, Searle Center for Teaching Excellence, Northwestern University, b-streitwieser@,northwestern.edu Bernhard Streitwieser is currently at the Centre for Comparative Education of the Humboldt Universitaet zu Berlin, Germany, sponsored by a Fulbright Senior Research Fellowship and a German Academic Exchange Service faculty grant. He is also a Senior Research Associate at Northwestern University's Searle Center for Teaching Excellence, a Teaching Associate in Northwestern's School of Education and Social Policy, and a former lecturer in the German Department. Between 2006-2008 he was the Associate Director of Northwestern's Study Abroad Office. His scholarship focuses on international and comparative education and mobility in European higher education.

Emily Le, PhD Candidate, Graduate School of Education, University of California, Los Angeles, emilyle@ucla.edu

Val Rust, Professor, Director, University of California, Los Angeles, Center for International and Development Education, rust@gseis.ucla.edu 